\title{
Synthesis and Characterization of $\mathbf{A g}_{2} \mathrm{~S}$ Layers Formed on Polypropylene
}

\author{
Valentina Krylova and Nijolė Dukštienè \\ Faculty of Chemical Technology, Kaunas University of Technology, Radvilenų Street 19, 50254 Kaunas, Lithuania \\ Correspondence should be addressed to V. Krylova; valentina.krylova@ktu.lt
}

Received 29 June 2012; Revised 20 August 2012; Accepted 28 August 2012

Academic Editor: Peter Chang

Copyright (C) 2013 V. Krylova and N. Dukštienè. This is an open access article distributed under the Creative Commons Attribution License, which permits unrestricted use, distribution, and reproduction in any medium, provided the original work is properly cited.

\begin{abstract}
Silver sulphide, $\mathrm{Ag}_{2} \mathrm{~S}$, layers on the surface of polypropylene (PP) film was formed by chemical bath deposition method (CBD). Film samples were characterised by X-ray photoelectron spectroscopy (XPS), attenuated total reflection Fourier transform infrared (ATR-FTIR) spectroscopy, scanning electron microscopy (SEM), atomic force microscopy (AFM), and X-ray diffraction analysis (XRD). The surface morphology, texture, and uniformity of the silver sulphide layers were formed on PP surface dependent on the number of polymer immersions in the precursor solution. XPS analysis confirmed that on the surface of the polypropylene film, a layer of $\mathrm{Ag}_{2} \mathrm{~S}$ was formed. ATR-FTIR and FTIR spectra analysis showed that the surface of $\mathrm{Ag}_{2} \mathrm{~S}$ layers is slightly oxidized. All

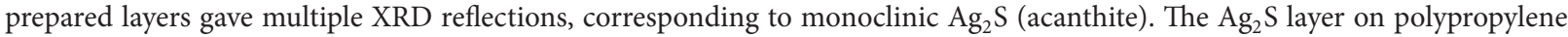
was characterized as an $\mathrm{Ag}^{+}$ion selective electrode in terms of potential response and detection limit. The electrode was also tested as an end-point electrode for argentometric titration of thiamine hydrochloride.
\end{abstract}

\section{Introduction}

Polymers modified by thin electrically conductive or semiconductive films of binary inorganic compounds, particularly of metal chalcogenides [1-4] represent a new class of materials-composites. The application of these composites is determined by their properties, wheares the latter depend significantly on the preparation method, even the chemical composition and structure of composites slightly change [5, $6]$.

In the last few years, there is a growing interest in $\mathrm{Ag}_{2} \mathrm{~S}$ films because of their unique electrical $[7,8]$, optical [9], photovoltaic [10], and thermoelectric properties $[11,12]$

These unique properties suggest potentially broad applications of $\mathrm{Ag}_{2} \mathrm{~S}$ films in various devices such as solar cells, super ionic conductors and semiconductors, photo detectors, photo thermal conversion, electroconductive electrodes, microwave shielding coating, gas sensors functioning at temperatures tending to room temperature, polarizer's of infrared radiation, and active absorbents of radio waves [5, 6, 13-15].

The properties of $\mathrm{Ag}_{2} \mathrm{~S}$ films can be successfully utilized by deposition its layers (either by in situ or ex situ methods) onto polymer surface, since a polymer can be easily designed into almost any shape required by a particular application. Additionally, the polymer can also act as the controlled environment for the growth of the film layers. Furthermore, the $\mathrm{Ag}_{2} \mathrm{~S} /$ polymer composites may exhibit new properties that differ from those of single $\mathrm{Ag}_{2} \mathrm{~S}$ films, arising from the spatial orientation and network arrangement. Therefore, the ability to prepare such composites on a large scale is an important goal of materials science.

The properties of $\mathrm{Ag}_{2} \mathrm{~S}$ /polymer composites are very sensitive to preparation technique and significantly depend on the nature of polymer on which $\mathrm{Ag}_{2} \mathrm{~S}$ layers are formed. Recently, there have been a number of papers suggesting different methods for the incorporation of silver sulphide nanocrystals in different polymer matrices and their characterization. The well-dispersed $\mathrm{Ag}_{2} \mathrm{~S}$ nanoparticles 
incorporated in polyvinylpyrrolidone (PVP)/fibre matrices using the electrospinning technique [16]. Kumar et al. [17] have applied a sonochemical method for the preparation of $\mathrm{Ag}_{2} \mathrm{~S}$ nanoparticles in the presence of polyvinyl alcohol. Composite thin films consisting of nanosized $\mathrm{Ag}$ and $\mathrm{Ag}_{2} \mathrm{~S}$ particles dispersed in nylon 11 thin films have been prepared by using a thermal relaxation technique [18]. Wang et al. developed a gas/solid reaction method based on surface initiated atom transfer radical polymerization (ATRP) for fabricating nanoparticles/polymer composite thin films, while preventing the aggregation of nanoparticles; thus the reaction may happen on the surface of composite thin films [19].

This present study focuses on the deposition of $\mathrm{Ag}_{2} \mathrm{~S}$ layers on the polypropylene (PP) by the chemical bath deposition method (CBD). PP film is characterized by many excellent properties than other polymers. This is a low density, high thermal resistance, high strength at high flexibility, resistance to cracking under stress and a very good chemical stability [20].

The CBD method is relatively simple and inexpensive, and highly reproducible technique. The technology is based on slow controlled precipitation of the $\mathrm{Ag}_{2} \mathrm{~S}$ through the reaction between $\mathrm{Ag}^{+}$and sulphur compounds as the sulphur source.

In the past decade, $\mathrm{Ag}_{2} \mathrm{~S}$ thin films by $\mathrm{CBD}$ method have been successfully prepared on silica [21], glass [22], biopolymer matrix [23], indium doted tin oxide (ITO) film [24], and polyamide (nylon) surfaces [25].

The sulphur precursors were usually thiourea [24], the elemental sulphur dissolved in a concentrated $\mathrm{NaOH}$ solution [26], thioacetamide [27], sodium sulphide [25], sodium thiosulphate [3], dimethylthiourea [6] and toxic carbon disulphide $\left(\mathrm{CS}_{2}\right)$ in ethanol [28]. The most pronounced role in the formation of the $\mathrm{Ag}_{2} \mathrm{~S}$ particles and consequently deposits has been played by the complexing agents. An ethylenediaminetetraacetate disodium salt (EDTA) [8] and ammonia solution [21] acting as a complexant for Ag ions or as a catalyst is usually employed to control the reaction rate. The commonly accepted underlying mechanism involves alkaline solution ( $\mathrm{pH} 6-10)$ as ammonia for $\mathrm{pH}$ adjustment [8] and higher temperature $30-80^{\circ} \mathrm{C}$ [21].

However, the adding of complexing agent increases experimental parameters whereas the nonaqueous medium is expensive or toxic generally.

In this paper we report on the depositing of $\mathrm{Ag}_{2} \mathrm{~S}$ layers by CBD from an acidic aqueous solution containing silver nitrate and an excess of sodium thiosulphate at $20^{\circ} \mathrm{C}$ temperature. The replacement of complexing agents with excess of sodium thiosulphate results to the simpler reaction mechanism. A reaction mechanism for depositing continuous $\mathrm{Ag}_{2} \mathrm{~S}$ layer has been examined, and the optimal precursor's concentrations in solution are suggested. The chemical composition, structural, and morphological properties of $\mathrm{Ag}_{2} \mathrm{~S}$ layer formed on polypropene surface have been investigated. The $\mathrm{Ag}_{2} \mathrm{~S}$ layer formed on polypropene was also tested as an indicator electrode for argentometric titration of thiamine hydrochloride (vitamin $\mathrm{B}_{1}$ ).

\section{Experimental}

$15 \mathrm{~mm} \times 70 \mathrm{~mm}$ size samples of nonoriented isotactic polypropylene (PP) film of $150 \mu \mathrm{m}$ thicknesses (Proline X998, KWH Plast, Finland) were used for the experiments.

Before $\mathrm{Ag}_{2} \mathrm{~S}$ formation process, the hydrophobic PP sample requires a previous surface treatment process in order to facilitate its adhesion properties. Polymer was treated for $25 \mathrm{~min}$ at $90^{\circ} \mathrm{C}$ with etching solution $\left(\mathrm{H}_{2} \mathrm{SO}_{4} / \mathrm{H}_{3} \mathrm{PO}_{4}(1: 1)\right.$, saturated with $\mathrm{CrO}_{3}$ ). The formation of $\mathrm{Ag}_{2} \mathrm{~S}$ layers on $\mathrm{PP}$ was carried out in the glass reactor. Etched PP films were immersed for $40 \mathrm{~min}$ in aqueous $\mathrm{Na}_{2} \mathrm{~S}_{2} \mathrm{O}_{3}\left(0.2 \mathrm{~mol} / \mathrm{dm}^{3}\right)$ and $\mathrm{AgNO}_{3}\left(0.08 \mathrm{~mol} / \mathrm{dm}^{3}\right)$ solutions at $20^{\circ} \mathrm{C}$ with $\mathrm{pH} 2.3$. Then obtained samples were removed from reaction solution, rinsed with distilled water and dried at room temperature. The $\mathrm{Ag}_{2} \mathrm{~S} / \mathrm{PP}$ samples were subjected for repetitive immersions in order to increase $\mathrm{Ag}_{2} \mathrm{~S}$ amount. The $\mathrm{Ag}_{2} \mathrm{~S} / \mathrm{PP}$ samples were repeatedly immersed in the freshly prepared reaction solution. The immersions procedure was repeated for 5 times.

Distilled water, and analytically pure $\mathrm{Na}_{2} \mathrm{~S}_{2} \mathrm{O}_{3} \cdot 5 \mathrm{H}_{2} \mathrm{O}$, $\mathrm{AgNO}_{3}$, reagents were used to prepare reaction solutions.

Solutions' $\mathrm{pH}$ was measured by using $\mathrm{pH}$-meter WTW330, with combinative glass and $\mathrm{Ag} / \mathrm{AgCl}$ electrode and temperature meter WTW SenTix 41 (Germany).

Before the chemical analysis, samples of PP strips plated with $\mathrm{Ag}_{2} \mathrm{~S}$ films have been mineralized. Samples were treated under heating with $6 \mathrm{~mol} / \mathrm{dm}^{3}$ nitric acid to oxidize sulphur compounds to sulphates. Heating with concentrated hydrochloric acid removed the excess of nitric acid. The resulting solution was poured into a $25 \mathrm{~cm}^{3}$ flask and made up to the mark with distilled water. Then the $5 \mathrm{~cm}^{3}$ of this solution was taken for the sulphur concentration determination, and remaining part was used to determine the silver concentration.

Sulphur concentration in the silver sulphide layer was determined turbidimetrically [29]. Sulphate ions in the range from $1 \mathrm{mg} / \mathrm{dm}^{3}$ to $15 \mathrm{mg} / \mathrm{dm}^{3}$ may be readily determined by utilising the reaction with barium chloride in a solution slightly acidified with hydrochloric acid to give barium sulphate. A glycerolethanol solution helped to stabilise the turbidity of the barium sulphate suspension. The measurement of the intensity of the transmitted light as a function of the concentration of the suspension of $\mathrm{BaSO}_{4}$ was carried out with a GENESYS 20 spectrophotometer (Thermo Spectronic, $U K)$, at a wavelength $\lambda=400 \mathrm{~nm}$. The standard deviation of the method with the photometric procedure in the range of concentrations from $5 \mathrm{mg} \mathrm{SO}_{4}{ }^{2-} \mathrm{dm}^{3}$ to $10 \mathrm{mg} \mathrm{SO}_{4}{ }^{2-} \mathrm{dm}^{3}$ was $\pm 8 \%$.

Silver concentration was determined with an atomic Perkin-Elmer absorption meter $503(\lambda=328 \mathrm{~nm})$. The sensitivity of the method is $0.06 \mu \mathrm{g} / \mathrm{cm}^{3}$ for $1 \% \mathrm{Ag}$ absorption.

The content of silver and sulphur was expressed as $\mu \mathrm{mol} / \mathrm{cm}^{2}$. Three samples of each PP strip plated with $\mathrm{Ag}_{2} \mathrm{~S}$ film have been used to determine the concentration of silver and sulphur.

The scanning electron microscope (SEM) Quantax 200 with a detector X Flash 4030 (Bruker AXS Microanalysis 
$\mathrm{GmbH}$, Germany) was applied for the obtained $\mathrm{Ag}_{2} \mathrm{~S}$ layers surface analysis.

The surface morphology of the films was investigated using an atomic force microscope (NANOTOP-206, Microtestmachines, Belarus). An ULTRASHARP Si cantilever (force constant $5.0 \mathrm{~N} / \mathrm{m}$, curvature radius less than $10 \mathrm{~nm}$ ) was used. The measurements were performed in the contact mode. The AFM characteristics: maximum scan field area up to $15 \times 15$ microns, measurement matrix up to $512 \times$ 512 points. The image processing and the analysis of scanning probe microscopy data were performed using a Windowsbased program (Surface View version 2.0).

XPS measurements were performed with a Vacuum Generator (VG) ESCALAB MKII spectrometer. The nonmonochromatic $\mathrm{Al} \mathrm{K \alpha}$ X-ray radiation $(h v=1486.6 \mathrm{eV})$ was used for excitation. The Al twin anode was powered at $14 \mathrm{kV}$ and $20 \mathrm{~mA}$. The photoelectron takeoff angle with respect to the sample surface normal was $90^{\circ}$, and XPs spectra of $A g 3 d_{5 / 2}, S 2 p_{3 / 2}$, and $O$ 1s were taken at a constant analyzer energy mode (at $20 \mathrm{eV}$ pass energy). The base pressure in the working chamber was kept bellow $5 \times 10^{-7} \mathrm{~Pa}$. The spectrometer was calibrated relative to $\mathrm{Ag}$ $3 \mathrm{~d}_{5 / 2}$ at $368.0 \pm 0.1 \mathrm{eV}$ and $\mathrm{Au} 4 \mathrm{f}_{7 / 2}$ at $83.8 \pm 0.1 \mathrm{eV}$. The quantitative elemental analysis was done by estimating peak areas and taking into account empirical sensitivity factors for each element [30]. A standard program was used for data processing (XPS spectra were treated by a Shirley-type background subtraction and fitted with mixed GaussianLorentzian functions). Binding energies were referenced to the C $1 \mathrm{~s}(284.5 \mathrm{eV})$ on unsputtered surfaces. All samples were scanned as received-without ion beam surface cleaning procedure. Assignation of the signals to specific structures or given oxidation state of elements analysed was done by comparison with data reported by NIST Standard Reference Database 20, Version 3.5 [31] and to the literature references.

The changes in chemical structure and binding configuration of a thin layer were analyzed by attenuated total reflectance (ATR) spectroscopy, since ATR spectroscopy is an often chosen technique as it may be used to obtain the spectra of the surfaces of the adhesive sides of a sample. ATR-FTIR spectra were recorded in the wavenumber range $4000-600 \mathrm{~cm}^{-1}$ by the compensation method. In the $600-100 \mathrm{~cm}^{-1}$ spectral region, were recorded FT-IR spectra. $\mathrm{Ag}_{2} \mathrm{~S}$ deposits were scraped with a nonmetallic scraper, and then scrapings were solid mixed with CsI, modulated into pellets and subjected to FT-IR spectroscopy. Spectra were recorded on a Perkin Elmer FT-IR Spectrum GX spectrophotometer (USA) by averaging 64 scans with a wave number resolution of $1 \mathrm{~cm}^{-1}\left(0.3 \mathrm{~cm}^{-1}\right)$ at room temperature.

$\mathrm{X}$-ray diffractometry was carried out under a Brag Brendan circuit on a diffractometer (Dron-6, Russia) using $\mathrm{Cu}$ $\mathrm{K} \alpha(\lambda=0.154178 \mathrm{~nm})$ radiation, $30 \mathrm{kV}$ voltage, and $30 \mu \mathrm{A}$ current. The scanning range was $2 \theta=22-60^{\circ}$. The scanning speed was $1^{\circ} \cdot \mathrm{min}^{-1}$. Results were registered in in situ mode with a computer, and X-ray diffractograms of samples were treated using the Search Match, Xfit, ConvX, Dplot95, and Photo Styler programs.
Potentials were measured by using modified microprocessor HI 2200 (Hanna Instruments USA) relative to the reference $\mathrm{Ag}, \mathrm{AgCl} / \mathrm{KCl}_{\text {(sat.) }}$ electrode. The indicator electrodes were $\mathrm{Ag}_{2} \mathrm{~S} / \mathrm{PP}$ samples. The potentiometric measurements were made with the following electrochemical cell $\mathrm{Ag} / \mathrm{AgCl} / \mathrm{KCl}_{\text {(sat.) }} / /$ sample solution $/ \mathrm{Ag}_{2} \mathrm{~S} / \mathrm{PP} / \mathrm{Ag}$. The $\mathrm{Ag}_{2} \mathrm{~S} / \mathrm{PP}$ electrode was soaked in $0.01 \mathrm{~mol} / \mathrm{dm}^{3} \mathrm{AgNO}_{3}$ solution for $2 \mathrm{~h}$ before each measurement.

The $0.100 \mathrm{~g}$ amount of vitamin $\mathrm{B}_{1}$ (thiamine hydrochloride CAS RN67-03-8) powder was dissolved in $20 \mathrm{~cm}^{3}$ of water. The resulting solution was poured into a $100 \mathrm{~cm}^{3}$ volumetric flask and made up to the mark with distilled water. $50 \mathrm{~cm}^{3}$ of the sample solution containing $50 \mathrm{mg}$ of thiamine was transferred into a beaker, $10 \mathrm{~cm}^{3}$ of distilled water or $10 \mathrm{~cm}^{3}$ of $1 \mathrm{~mol} / \mathrm{dm}^{3} \mathrm{NaOH}$ was added, and resulting solution was titrated with $0.01 \mathrm{~mol} / \mathrm{dm}^{3}$ silver nitrate solution in $0.5 \mathrm{~cm}^{3}$ increments using $\mathrm{Ag}_{2} \mathrm{~S} / \mathrm{PP}$ membrane electrode. The end point of the titration was determined from the Gran plots.

\section{Results and Discussion}

3.1. $\mathrm{Ag}_{2} \mathrm{~S}$ Layers Formation Mechanism on a PP Film in Chemical Bath Deposition Process. The silver sulphide layers may be deposited on the PP films by immersing polymer in aqueous solutions of silver nitrate $\left(\mathrm{AgNO}_{3}\right)$ and sodium thiosulphate $\left(\mathrm{Na}_{2} \mathrm{~S}_{2} \mathrm{O}_{3}\right)$. When a soluble sodium thiosulphate reacts with a silver nitrate, insoluble silver thiosulphate, $\mathrm{Ag}_{2} \mathrm{~S}_{2} \mathrm{O}_{3}$, (the solubility product for $\mathrm{Ag}_{2} \mathrm{~S}_{2} \mathrm{O}_{3}$ is $K_{\text {sp }}=1 \times$ $10^{-13}$ [32]) is formed by reaction

$$
2 \mathrm{AgNO}_{3}+\mathrm{Na}_{2} \mathrm{~S}_{2} \mathrm{O}_{3} \longrightarrow \mathrm{Ag}_{2} \mathrm{~S}_{2} \mathrm{O}_{3}+2 \mathrm{NaNO}_{3}
$$

$\mathrm{Ag}_{2} \mathrm{~S}_{2} \mathrm{O}_{3}$ is comparatively unstable and hydrolyzes to release $\mathrm{Ag}_{2} \mathrm{~S}$ into the reaction solution:

$$
\mathrm{Ag}_{2} \mathrm{~S}_{2} \mathrm{O}_{3}+\mathrm{H}_{2} \mathrm{O} \longrightarrow \mathrm{Ag}_{2} \mathrm{~S}+\mathrm{H}_{2} \mathrm{SO}_{4}
$$

The initial experiments indicated that the usage of $0.2-0.1 \mathrm{~mol} / \mathrm{dm}^{3} \quad \mathrm{AgNO}_{3}$ and $0.2-0.1 \mathrm{~mol} / \mathrm{dm}^{3} \quad \mathrm{Na}_{2} \mathrm{~S}_{2} \mathrm{O}_{3}$ solutions for $\mathrm{Ag}_{2} \mathrm{~S}$ layers depositing on PP, results in quick settle of $\mathrm{Ag}_{2} \mathrm{~S}$ precipitates on reactor bottom and layers on polypropylene could not be formed. Therefore, the slow precipitation of silver sulphide particles is essential for the formation of the layers on polymer surface.

In order to diminish the rate of silver sulphide formation process, the silver ions were complexed by thiosulphate ions. When the sodium thiosulphate solution was added into the aqueous silver nitrate solution, silver ions were coordinating with some thiosulphate groups, resulting in the relatively high silver ions concentration around these groups. In the presence of thiosulphate excess, the soluble $\left[\mathrm{Ag}_{2}\left(\mathrm{~S}_{2} \mathrm{O}_{3}\right)_{2}\right]^{2-}$, $\left[\mathrm{Ag}_{2}\left(\mathrm{~S}_{2} \mathrm{O}_{3}\right)_{3}\right]^{4-}$ and $\left[\mathrm{Ag}_{2}\left(\mathrm{~S}_{2} \mathrm{O}_{3}\right)_{4}\right]^{6-}$ complexes are formed.

In nitric acid solution, these complexes decomposed, and they slowly released $\mathrm{S}^{2-}$ ions combined with the $\mathrm{Ag}^{+}$ions to form a very insoluble $\mathrm{Ag}_{2} \mathrm{~S}$ (the solubility product for $\mathrm{Ag}_{2} \mathrm{~S}$ is $\left.K_{\text {sp }}=7.2 \times 10^{-50}[32]\right)$ nuclei on some special sites of PP.

Simultaneously, the side reactions are also possible. 
TABLE 1: Chemical composition of $\mathrm{Ag}_{2} \mathrm{~S}$ layers formed in PP matrices, depending on the film immersions time.

\begin{tabular}{lccc}
\hline Parameter & \multicolumn{3}{c}{ Immersions time, min } \\
& 40 & 120 & 200 \\
\hline Silver concentration $c_{\mathrm{Ag}}, \mu \mathrm{mol} \mathrm{cm}$ & & $2.970 \pm 0.006$ & $3.779 \pm 0.004$ \\
Sulfur concentration $c_{\mathrm{S}}, \mu \mathrm{mol} \mathrm{cm}$ & $1.312 \pm 0.005$ & $1.485 \pm 0.008$ & $2.065 \pm 0.006$ \\
\hline
\end{tabular}

The thiosulphate can react with nitric acid forming thiosulphuric acid by reaction:

$$
\mathrm{Na}_{2} \mathrm{~S}_{2} \mathrm{O}_{3}+2 \mathrm{HNO}_{3} \longrightarrow \mathrm{H}_{2} \mathrm{~S}_{2} \mathrm{O}_{3}+2 \mathrm{NaNO}_{3}
$$

The formed thiosulphuric acid may slowly decompose, and the new structural units such as elemental sulphur appear:

$$
\mathrm{H}_{2} \mathrm{~S}_{2} \mathrm{O}_{3} \longrightarrow \mathrm{S}+\mathrm{SO}_{2}+\mathrm{H}_{2} \mathrm{O}
$$

Elemental sulphur can dissolve in nitric acid by reaction:

$$
\mathrm{S}+2 \mathrm{HNO}_{3} \longrightarrow \mathrm{H}_{2} \mathrm{SO}_{4}+2 \mathrm{NO}
$$

Silver nitrate and sulphur acid can react to form silver sulphate:

$$
2 \mathrm{AgNO}_{3}+\mathrm{H}_{2} \mathrm{SO}_{4} \longrightarrow \mathrm{Ag}_{2} \mathrm{SO}_{4}+2 \mathrm{HNO}_{3}
$$

The incorporation of impurities such as a silver sulphate and sulphur is quite possible in the bulk $\mathrm{Ag}_{2} \mathrm{~S}$ layer.

It was found that the $0.08 \mathrm{~mol} / \mathrm{dm}^{3} \quad \mathrm{AgNO}_{3}$ and $0.20 \mathrm{~mol} / \mathrm{dm}^{3} \mathrm{Na}_{2} \mathrm{~S}_{2} \mathrm{O}_{3}$ solutions are the most suitable for the formation of silver sulphide layers on polypropylene surface at $\mathrm{pH} 2.3$ and $20^{\circ} \mathrm{C}$ temperature.

3.2. Chemical Analysis of $\mathrm{Ag}_{2} \mathrm{~S}$ Layers. As mentioned above, the preparation method influences the composition and properties of sulphide layers. Therefore, the initial stage of the work was aimed to establish the chemical composition of the deposited silver sulphide.

The chemical composition of silver sulphide layer obtained for different PP film immersion time in $0.08 \mathrm{~mol} / \mathrm{dm}^{3} \mathrm{AgNO}_{3}$ and $0.20 \mathrm{~mol} / \mathrm{dm}^{3} \mathrm{Na}_{2} \mathrm{~S}_{2} \mathrm{O}_{3}$ solutions at $20^{\circ} \mathrm{C}$ is presented in Table 1 . The molar ratios of silver to sulphur show that the stoichiometric silver sulphide and nonsulphide sulphur can coexist in synthesised layers.

3.3. Morphology of $\mathrm{Ag}_{2} \mathrm{~S}$ Layers. Figure 1 shows the representative SEM images of an $\mathrm{Ag}_{2} \mathrm{~S}$ layers on PP surface formed after 5 immersions ( $40 \mathrm{~min}$ each) of polymer in precursor solution. The sulphide surface exhibits nonhomogeneous morphology. The irregularly shaped grains join to form different sized islands on PP surfaces. The maximum size of islands is $19.5 \times 47 \mu \mathrm{m}$ and the smallest $7.8 \times 8 \mu \mathrm{m}$. The large number of micro bumps and irregularly spread clusters are also visible.

The AFM images of $\mathrm{Ag}_{2} \mathrm{~S}$ layers on PP surface are shown in Figures 2 and 3. The $\mathrm{Ag}_{2} \mathrm{~S}$ layer exhibits a graintype surface morphology; however, the size of grains, like

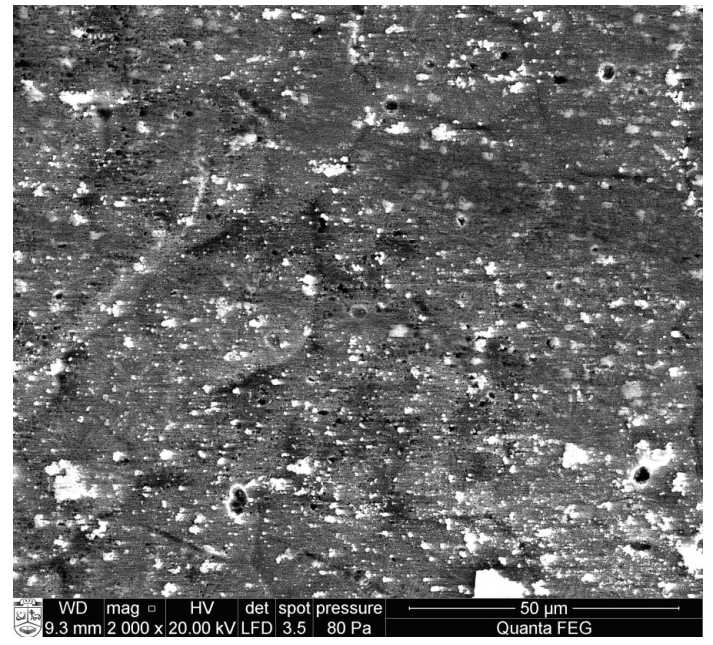

FIGURE 1: SEM image of $\mathrm{Ag}_{2} \mathrm{~S}$ layer formed on etched PP surface which was immersed in $\mathrm{AgNO}_{3} / \mathrm{Na}_{2} \mathrm{~S}_{2} \mathrm{O}_{3}$ solution 5 times at $20^{\circ} \mathrm{C}$.

the roughness of layer depends on the number of polymer immersion time in precursor solution.

When the polymer was immersed for 1 cycle in precursor solution, the irregular growth of different shaped grains is observed (Figure 2). The height of grains changed from $36 \mathrm{~nm}$ to $108 \mathrm{~nm}$, and the average width was about $148 \mathrm{~nm}$. In the local regions of layer surface, some of grains coalescence forming aggregates. The width of aggregates changed from 0.54 to $0.97 \mu \mathrm{m}$. The maximum height of the aggregates was about $138 \mathrm{~nm}$. The appreciable numbers of bumps is also observed on polymer surface (Figures 2(a) and 2(b)). The root mean square roughness $\left(R_{q}\right)$ was $25.9 \mathrm{~nm}$, while an average roughness $\left(R_{a}\right)$ was about $20.2 \mathrm{~nm}$. The $R_{q}$ value is greater than $R_{a}$, which support the rough morphology of $\mathrm{Ag}_{2} \mathrm{~S}$ layer surface.

The increase of polymer immersions times of in precursor solution leads to PP surface fulfillment. When the number of immersions was increased up to 5 (Figure 3), the rather large agglomerates composed of the different size particles are observed on surface. The width of aggregates changed from 0.56 to $1.6 \mu \mathrm{m}$. The maximum height of the aggregates increased up to $162 \mathrm{~nm}$. On the other hand, in the regions surrounding aggregates, the numerous grains are still observed. The width of grains varied from 28 to $200 \mathrm{~nm}$, while the height of grains equaled to $46-48 \mathrm{~nm}$. The parameters $R_{q}$ and $R_{a}$ are of higher magnitudes, namely, about 33.8 and $25.5 \mathrm{~nm}$, respectively, suggesting a rather rough surface.

3.4. XPS Analysis of Thin $\mathrm{Ag}_{2} \mathrm{~S}$ Layers. $\mathrm{Ag}_{2} \mathrm{~S}$ layers deposited on PP surface were examined by XPS measurements. The core 
TABLE 2: XPS results derived from the curve fitted deconvoluted spectra.

\begin{tabular}{|c|c|c|c|c|c|c|c|}
\hline $\begin{array}{l}\text { Immersions } \\
\text { time, min }\end{array}$ & Element & $\begin{array}{c}\text { Atomic } \\
\text { percentage, \% }\end{array}$ & $\begin{array}{l}\text { Binding } \\
\text { energy, eV }\end{array}$ & NIST data & $\begin{array}{l}\text { Oxidation } \\
\text { state }\end{array}$ & $\begin{array}{c}\text { Attribution } \\
\text { to structural } \\
\text { element found in }\end{array}$ & $\begin{array}{c}\text { Relative } \\
\text { percentage, } \%\end{array}$ \\
\hline \multirow{9}{*}{40} & \multirow{3}{*}{$\operatorname{Ag} 3 d_{5 / 2}$} & \multirow{3}{*}{33.33} & \multirow{3}{*}{368.5} & 368.1 & & $\mathrm{Ag}_{2} \mathrm{~S}$ & \multirow{3}{*}{100} \\
\hline & & & & 368.4 & +1 & $\mathrm{Ag}_{2} \mathrm{O}$ & \\
\hline & & & & 368.3 & & $\mathrm{Ag}_{2} \mathrm{SO}_{4}$ & \\
\hline & \multirow{3}{*}{$\mathrm{S} 2 \mathrm{p}_{3 / 2}$} & \multirow{3}{*}{22.23} & 160.8 & 160.7 & -2 & $\mathrm{Ag}_{2} \mathrm{~S}$ & 62.90 \\
\hline & & & 163.0 & 163.1 & 0 & $-S-S-$ & 23.65 \\
\hline & & & 168.8 & 168.6 & +6 & $\mathrm{~S}(\mathrm{VI})-\mathrm{O}$ & 13.45 \\
\hline & \multirow{3}{*}{$\mathrm{O} 1 \mathrm{~s}$} & \multirow{3}{*}{44.44} & 531.0 & 530.9 & \multirow{3}{*}{-2} & Ag-O & 18.55 \\
\hline & & & 532.1 & 532.0 & & $\mathrm{Ag}_{2} \mathrm{SO}_{4}$ & 46.52 \\
\hline & & & 533.3 & 533.3 & & $\mathrm{O}_{2}$ (adsorbed) & 34.93 \\
\hline \multirow{9}{*}{120} & \multirow{3}{*}{$\operatorname{Ag} 3 d_{5 / 2}$} & \multirow{3}{*}{50.70} & \multirow{3}{*}{368.2} & 368.1 & & $\mathrm{Ag}_{2} \mathrm{~S}$ & \multirow{3}{*}{100} \\
\hline & & & & 368.4 & +1 & $\mathrm{Ag}_{2} \mathrm{O}$ & \\
\hline & & & & 368.3 & & $\mathrm{Ag}_{2} \mathrm{SO}_{4}$ & \\
\hline & \multirow{3}{*}{$\mathrm{S} 2 \mathrm{p}_{3 / 2}$} & \multirow{3}{*}{24.67} & 161.0 & 160.7 & -2 & $\mathrm{Ag}_{2} \mathrm{~S}$ & 69.98 \\
\hline & & & 163.3 & 163.1 & 0 & $-S-S-$ & 16.65 \\
\hline & & & 168.4 & 168.6 & +6 & $\mathrm{~S}(\mathrm{VI})-\mathrm{O}$ & 13.37 \\
\hline & \multirow{3}{*}{$\mathrm{O} 1 \mathrm{~s}$} & \multirow{3}{*}{24.63} & 531.2 & 530.9 & & Ag-O & 16.77 \\
\hline & & & 532.0 & 532.0 & -2 & $\mathrm{Ag}_{2} \mathrm{SO}_{4}$ & 65.60 \\
\hline & & & 533.4 & 533.3 & -2 & $\mathrm{O}_{2}$ (adsorbed) & 17.63 \\
\hline \multirow{9}{*}{200} & \multirow{3}{*}{$\operatorname{Ag} 3 \mathrm{~d}_{5 / 2}$} & \multirow{3}{*}{40.68} & \multirow{3}{*}{368.0} & 368.1 & & $\mathrm{Ag}_{2} \mathrm{~S}$ & \multirow{3}{*}{100} \\
\hline & & & & 368.4 & +1 & $\mathrm{Ag}_{2} \mathrm{O}$ & \\
\hline & & & & 368.3 & & $\mathrm{Ag}_{2} \mathrm{SO}_{4}$ & \\
\hline & \multirow{3}{*}{$\mathrm{S} 2 \mathrm{p}_{3 / 2}$} & \multirow{3}{*}{22.18} & 160.8 & 160.7 & -2 & $\mathrm{Ag}_{2} \mathrm{~S}$ & 60.50 \\
\hline & & & 163.0 & 163.1 & 0 & $-S-S-$ & 23.16 \\
\hline & & & 168.8 & 168.6 & +6 & $\mathrm{~S}(\mathrm{VI})-\mathrm{O}$ & 16.34 \\
\hline & \multirow{3}{*}{$\mathrm{O} 1 \mathrm{~s}$} & \multirow{3}{*}{37.17} & 530.8 & 530.9 & \multirow{3}{*}{-2} & Ag-O & 16.08 \\
\hline & & & 531.9 & 532.0 & & $\mathrm{Ag}_{2} \mathrm{SO}_{4}$ & 68.93 \\
\hline & & & 533.3 & 533.3 & & $\mathrm{O}_{2}$ (adsorbed) & 14.99 \\
\hline
\end{tabular}

levels S 2p, $A g 3 d_{5 / 2}$, and O 1s spectra were measured. During formation of the $\mathrm{Ag}_{2} \mathrm{~S}$ layer on the surface of polypropylene, all processes proceed in an open medium; therefore, it is not possible to avoid ambient effects. Since the surface of this layer is active, it adsorbs oxygen, water, and other contaminants $[33,34]$. The sulphide layer on the PP surface is non-homogeneous (Figure 1) enabling an easy contact of the atmospheric oxygen with silver and sulphur ions. Therefore, the composition of the $\mathrm{Ag}_{2} \mathrm{~S}$ layer on the surface can differ from the chemical composition of the entire layer. It is necessary to emphasize that the XPS method investigates a very thin (up to few $\mathrm{nm}$ ) surface layers.

The analysis of experimental XPS data shows that the composition of $\mathrm{Ag}_{2} \mathrm{~S}$ layers formed at different immersions time is rather similar. They consist of silver, sulphur, and oxygen in various combinations (Table 2).

The $S 2 p_{3 / 2}$ spectra for film samples show three peaks at about $160.8,163.0$, and $168.8 \mathrm{eV}$.

According to the NIST XPS date base [31], the $S 2 p_{3 / 2}$ peak at $160.8 \mathrm{eV}$ is assigned to $\mathrm{Ag}-\mathrm{S}-\mathrm{Ag}$ bonding of $\mathrm{Ag}_{2} \mathrm{~S}$, and the $\mathrm{S} 2 \mathrm{p}_{3 / 2}$ peak at $163.0 \mathrm{eV}$ is assigned to $-\mathrm{S}-\mathrm{S}$-bonding. The latter is about from 13.77 to $23.66 \%$ of $S 2 \mathrm{p}_{3 / 2}$ peak (Table 2 ), depending on the immersion time. This peak probably resulted from the chemisorbed sulphide nanoparticles, rather than the incorporation of elemental sulphur, since the $S 2 p_{3 / 2}$ peak occurs above $164.0 \mathrm{eV}$ [35]. A spectral line at higher energies of about $168 \mathrm{eV}$ originates from oxidized sulphur [36]. For all samples, the higher energy $S 2 p_{3 / 2}$ peak position at $168.8 \mathrm{eV}$ well coincides with the known $\mathrm{Ag}_{2} \mathrm{SO}_{4}$ position $(168.6 \mathrm{eV})[31]$; therefore, we assign this peak to sulphur(VI) bond to oxygen.

According to the literature data, Ag $3 \mathrm{~d}_{5 / 2}$ core level, located at $368.3 \mathrm{eV}$, corresponds to binding energy of metallic silver [37], while the line at lower energies of $367.8 \mathrm{eV}$ indicates the presence of $\mathrm{Ag}^{+}[38,39]$. The peaks of $\mathrm{Ag} 3 \mathrm{~d}_{5 / 2}$ at $368 \mathrm{eV}$ and $\mathrm{S} 2 \mathrm{p}_{3 / 2}$ at $161.2 \mathrm{eV}$ are the characteristic binding energies for the $\mathrm{Ag}_{2} \mathrm{~S}$ [26], whereas the $\mathrm{Ag} 3 \mathrm{~d}_{5 / 2}$ line for $\mathrm{Ag}$ bounded to sulphur has been reported at $368.9 \mathrm{eV}$ [40]. The $\mathrm{Ag} 3 \mathrm{~d}_{5 / 2}$ component with binding energy of $367.9 \mathrm{eV}$ was reported for $\mathrm{Ag}_{2} \mathrm{O}$ [41], while for $\mathrm{AgO}$, it shifted by 


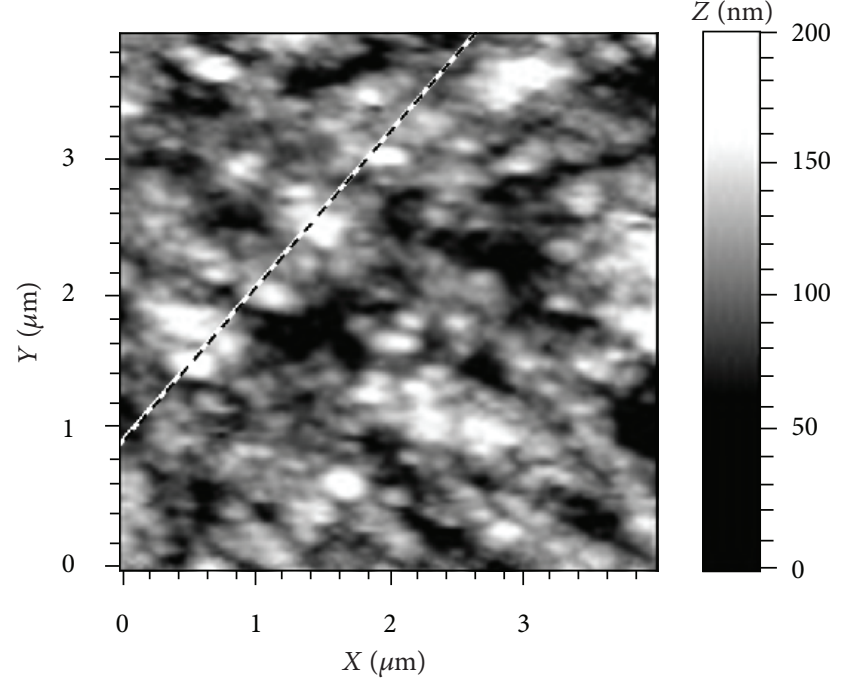

(a)

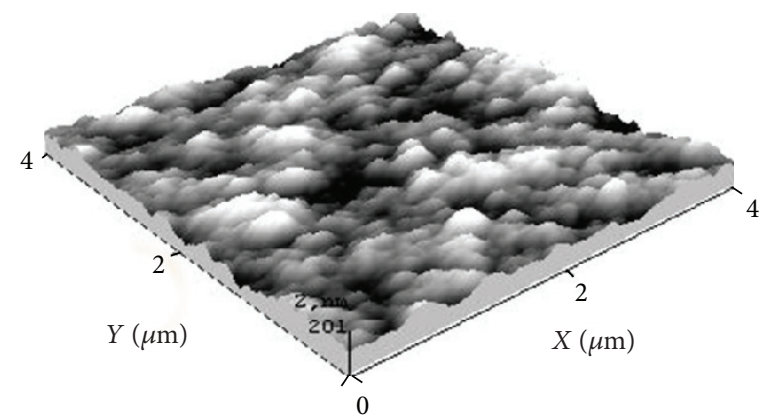

(b)

FIgURE 2: AFM image of $\mathrm{Ag}_{2} \mathrm{~S}$ layer on etched PP surface immersed for 1 time in $\mathrm{AgNO}_{3} / \mathrm{Na}_{2} \mathrm{~S}_{2} \mathrm{O}_{3}$ solution at $20^{\circ} \mathrm{C}$ : (a) $2 \mathrm{D}$ topography; (b) 3D topography.

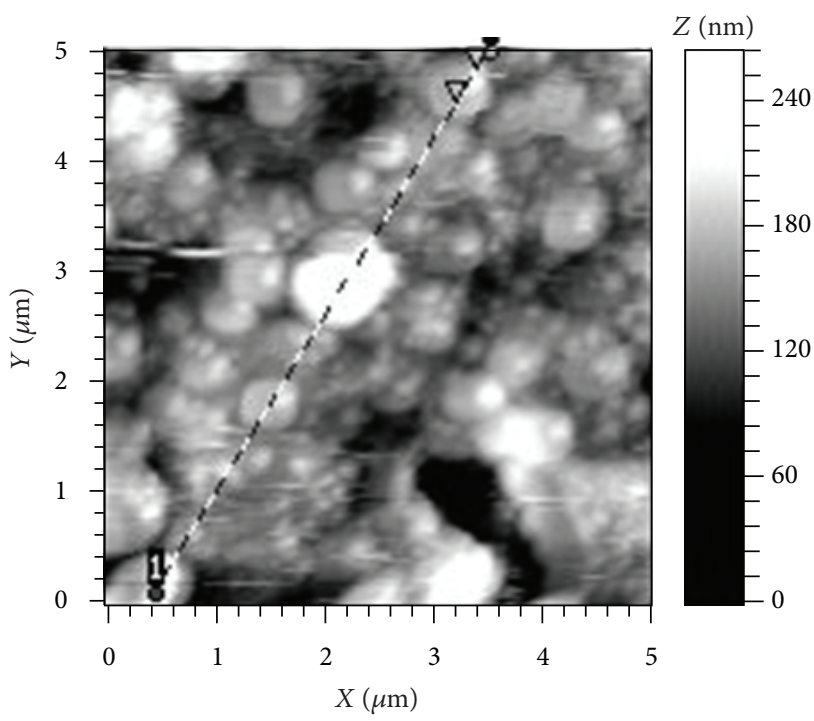

(a)

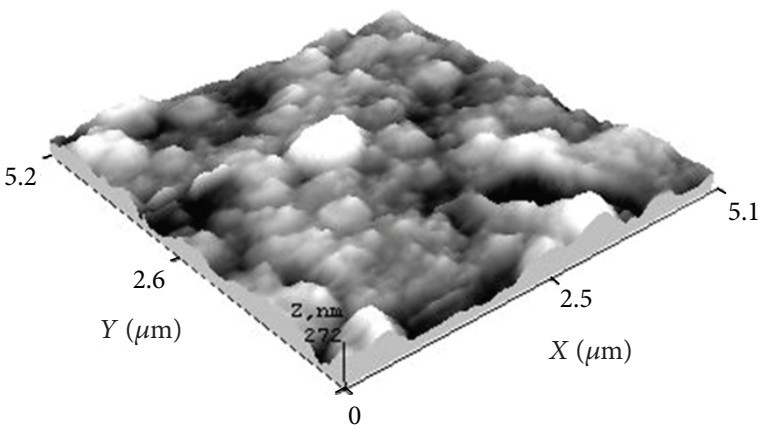

(b)

Figure 3: AFM image of $\mathrm{Ag}_{2} \mathrm{~S}$ layer on etched PP surface immersed for 5 times in $\mathrm{AgNO}_{3} / \mathrm{Na}_{2} \mathrm{~S}_{2} \mathrm{O}_{3}$ solution at $20^{\circ} \mathrm{C}$ : (a) $2 \mathrm{D}$ topography; (b) 3D topography.

$0.5 \mathrm{eV}$ to value of $367.4 \mathrm{eV}$ [42]. Summarising analysis data of experimental $\mathrm{Ag} 3 \mathrm{~d}_{5 / 2}$ peak detected in the range between 368.5 to $368.0 \mathrm{eV}$ (Table 2), it is difficult to distinguish between $\mathrm{Ag}-\mathrm{O}-\mathrm{Ag}$ and $\mathrm{Ag}-\mathrm{S}-\mathrm{Ag}$ bond position. However, concerning the $S 2 p_{3 / 2}$ core levels (Table 2), it can be noted that the majority of the sulphur is in the $\mathrm{S}^{2-}$ state, confirming that the obtained layers are indeed $\mathrm{Ag}_{2} \mathrm{~S}$.

The XPS spectrum for $\mathrm{O} 1 \mathrm{~s}$ can be deconvoluted into free different contributions with binding energies at around 531.0, 532.0, and 533.3 eV (Table 2). The peak at around $533.3 \mathrm{eV}$ on the high binding energy side of the $\mathrm{O} 1 \mathrm{~s}$ region was ascribed to the atmospheric oxygen adsorbed on the layer surface. The peak with binding energy of $529.5 \mathrm{eV}$ was reported for $\mathrm{Ag}_{2} \mathrm{O}$ [41]. Two peaks at 528.7 and $531.0 \mathrm{eV}$ are observed in the $\mathrm{O} 1 \mathrm{~s}$ spectrum of $\mathrm{AgO}$ [43]. The presence of component at $531.0 \mathrm{eV}$ in all studied $\mathrm{O} 1 \mathrm{~s}$ spectra confirms that the silver sulphide surface layer oxidized.

3.5. ATR-FTIR Analysis of $\mathrm{Ag}_{2} \mathrm{~S}$ Layers. Seeking to investigate the changes of the chemical composition of the untreated PP, etched PP, and PP samples, coated with a layer of silver sulphide, ATR-FTIR spectra (Figure 4) were recorded. 


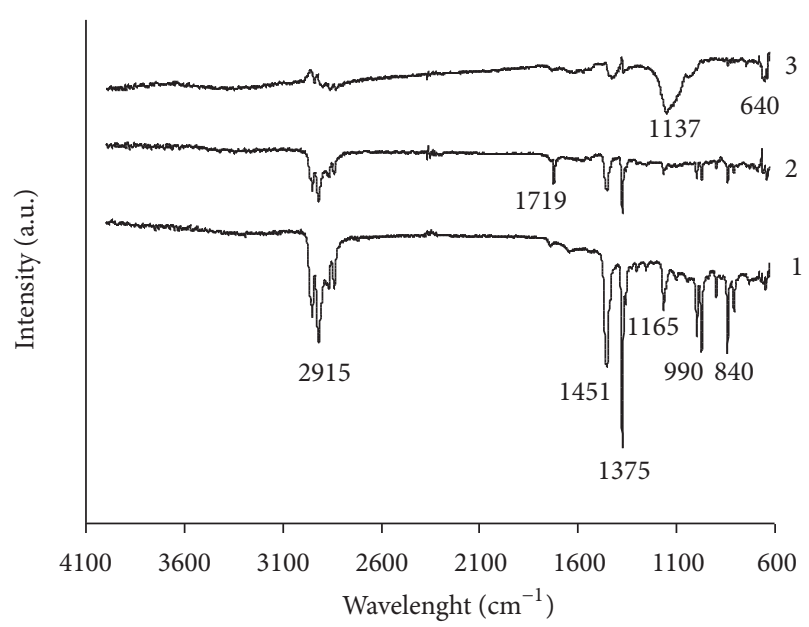

(a)

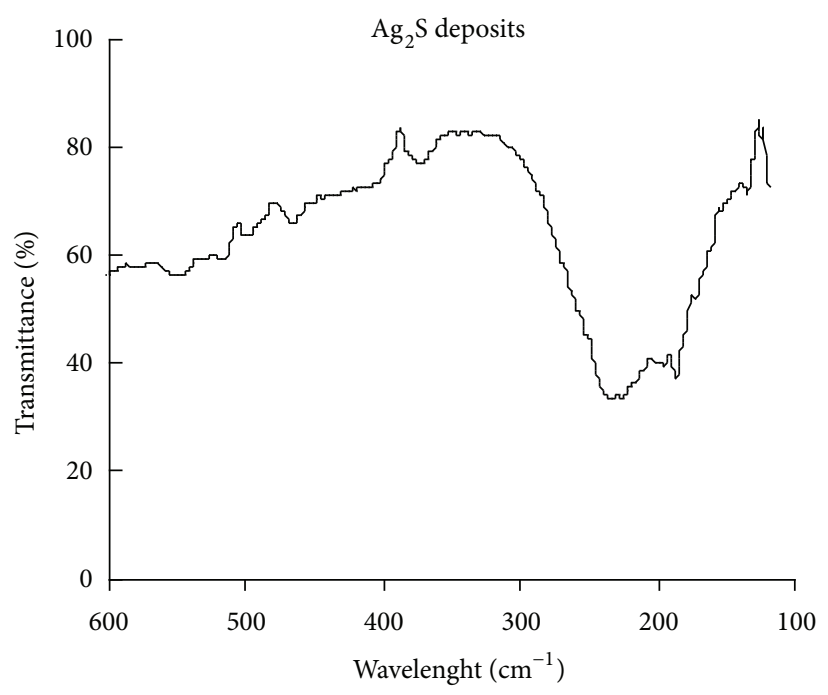

(b)

FIgURE 4: (a) ATR-FTIR spectra of untreated polypropylene (1), etched PP (2), and etched PP samples covered with $\mathrm{Ag}_{2} \mathrm{~S}$ layer after 5 immersions in $\mathrm{AgNO}_{3} / \mathrm{Na}_{2} \mathrm{~S}_{2} \mathrm{O}_{3}$ solution at $20^{\circ} \mathrm{C}$ : (3); (b) FTIR spectrum of scrapped $\mathrm{Ag}_{2} \mathrm{~S}$ deposits.

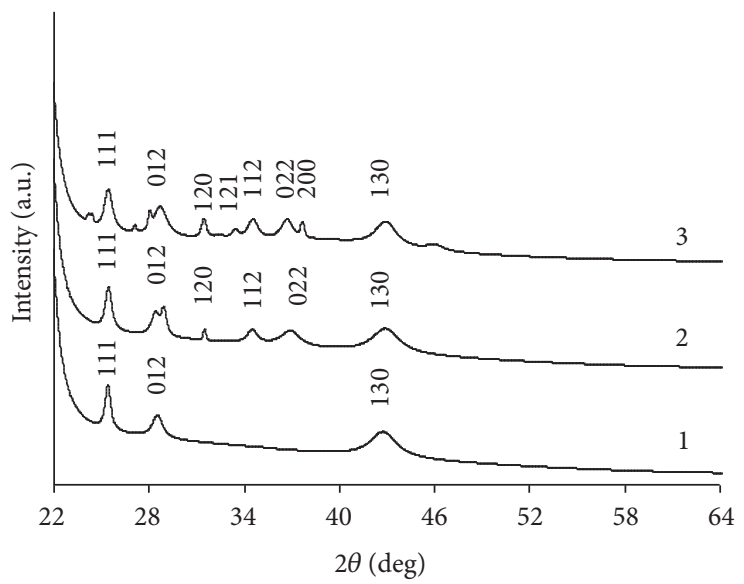

Figure 5: X-ray diffractograms of the $\mathrm{Ag}_{2} \mathrm{~S}$ layers formed on PP in $0.08 \mathrm{~mol} / \mathrm{dm}^{3} \mathrm{AgNO}_{3}$ and $0.20 \mathrm{~mol} / \mathrm{dm}^{3} \mathrm{Na}_{2} \mathrm{~S}_{2} \mathrm{O}_{3}$ solutions at $20^{\circ} \mathrm{C}$ for different immersions time, min: 1: 40; 2: 140; 3: 200.

Figure 4(a) shows ATR-FTIR spectra of untreated (curve 1 ), etched polypropylene film (curve 2), and PP samples, coated with a layer of silver sulphide (curve 3 ) in the range of 4000 to $600 \mathrm{~cm}^{-1}$, and Figure 4(b) displays FTIR spectrum of PP samples, coated with a layer of silver sulphide in the range of 600 to $100 \mathrm{~cm}^{-1}$.

The PP sample ATR-FTIR spectrum (Figure 4(a), curve 1) displays absorption peaks which coincide well with the reported literature data [44]. In polypropylene spectrum, moderate absorption peaks of deformation vibrations of the plane methylene group arise in the spectral range of 1445 to $1485 \mathrm{~cm}^{-1}$, and methyl groups vibrations are registered in range of $1430-1470 \mathrm{~cm}^{-1}$ or 1365 to $1395 \mathrm{~cm}^{-1}$. These peaks in our spectrum appear at $1451 \mathrm{~cm}^{-1}$ and $1375 \mathrm{~cm}^{-1}$, respectively. A broad and intense band at around $2915 \mathrm{~cm}^{-1}$ was attributed to vibrations of $\mathrm{CH}$ bands. The absorption features at 840,1000 , and $1170 \mathrm{~cm}^{-1}$ are characteristic vibrations of terminal unsaturated $\mathrm{CH}_{2}$ groups present in isotactic $\mathrm{PP}$ [44]. These characteristic features in our experimental spectrum are observed at 840,990 , and $1165 \mathrm{~cm}^{-1}$ (Figure 4(a), curve $1)$.

ATR-FTIR spectrum of etched PP sample (Figure 4(a), curve 2) shows some changes. The characteristic peaks sharply diminish, and a new signal appears at $1719 \mathrm{~cm}^{-1}$. This signal is probably due to superposition of signals at 1710 and $1724 \mathrm{~cm}^{-1}$, characteristic of carboxylic and carboxylic stretching vibrations, respectively [45]. The spectrum of etched PP confirms that the oxidizing pretreatment of polypropylene increases surface hydrophility. Better hydrophilic characteristics of PP surface induce electrostatic 


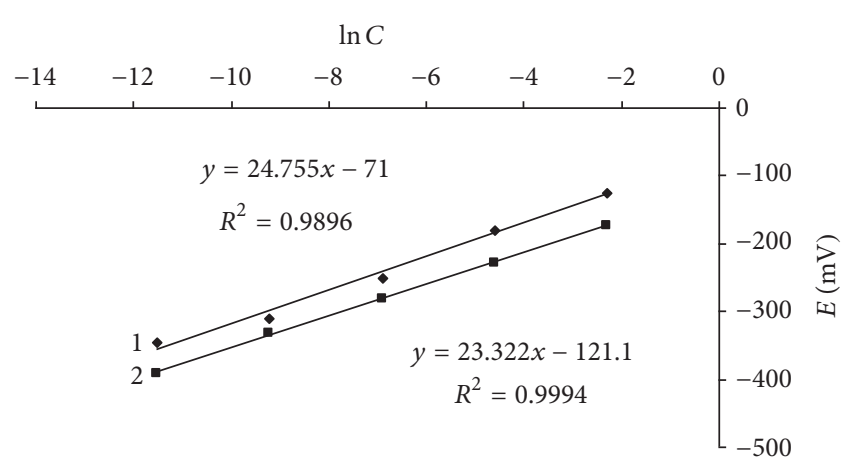

FIgURE 6: Change of $\mathrm{Ag}_{2} \mathrm{~S} / \mathrm{PP}$ electrode potential with $\mathrm{Ag}^{+}$ion concentration, mol dm ${ }^{-3}$. Electrode prepared in $0.08 \mathrm{~mol} / \mathrm{dm}^{3}$ $\mathrm{AgNO}_{3}$ and $0.20 \mathrm{~mol} / \mathrm{dm}^{3} \mathrm{Na}_{2} \mathrm{~S}_{2} \mathrm{O}_{3}$ solutions at $20^{\circ} \mathrm{C}$ for different immersions time, min: 1: 140; 2: 200.

interactions between the charged sites of the polymer and the sulphide particles, providing its adhesion to the polymeric surface.

The ATR-FTIR spectrum of PP samples covered with $\mathrm{Ag}_{2} \mathrm{~S}$ layers (Figure 4(a), curve 3) shows that the intensity of peaks, characterising etched PP, decreased, and two new broad vibration bands at $1137 \mathrm{~cm}^{-1}$ and $640 \mathrm{~cm}^{-1}$ appeared. On the grounds of the literature data [46-48], the bands in the range of the wavenumbers $1000-1250 \mathrm{~cm}^{-1}$ correspond to vibration frequencies of the $\mathrm{S}-\mathrm{O}$ band: in the range of $1186-1224 \mathrm{~cm}^{-1}$, it corresponds to the asymmetric valence $\mathrm{S}-\mathrm{O}$ vibrations, $v_{\text {as }}(\mathrm{S}-\mathrm{O})$, while the peaks corresponding to the symmetric valence $\mathrm{S}-\mathrm{O}$ vibrations, $v_{s}(\mathrm{~S}-\mathrm{O})$, appear in the interval of $1018-1095 \mathrm{~cm}^{-1}$. According to the reported data [47], the sulphates vibration modes arise in the wavenumber range of $1080-1130 \mathrm{~cm}^{-1}$ and $610-680 \mathrm{~cm}^{-1}$. The scissoring vibration mode of the $\mathrm{O}-\mathrm{S}-\mathrm{O}$ group occurs as a strong band between $400-650 \mathrm{~cm}^{-1}$ [49].

Therefore, the peak of $640 \mathrm{~cm}^{-1}$ to the symmetric deformation of $\mathrm{O}-\mathrm{S}-\mathrm{O}$ vibrations, $\delta_{s}(\mathrm{O}-\mathrm{S}-\mathrm{O})$, and the peak of $1137 \mathrm{~cm}^{-1}$ corresponds to the asymmetric deformation of $\mathrm{O}-\mathrm{S}-\mathrm{O}$ vibrations, $\delta_{\text {as }}(\mathrm{O}-\mathrm{S}-\mathrm{O})$.

The broad absorption band maximum at $237 \mathrm{~cm}^{-1}$ observed in FTIR spectrum (Figure 4(b)) corresponds to characteristic vibrations of $\mathrm{Ag}-\mathrm{S}$ and is in good agreement with reported data for $\mathrm{Ag}_{2} \mathrm{~S}[48,50]$.

3.6. XRD Analysis of Thin $\mathrm{Ag}_{2} \mathrm{~S}$ Film Layers. The deposited $\mathrm{Ag}_{2} \mathrm{~S}$ layers were subjected to X-ray diffractometry to investigate the crystallographic structure of these layers. Structural studies of the $\mathrm{Ag}_{2} \mathrm{~S}$ deposits on polypropylene are limited by the crystallinity of the PP film itself. The intensity of its peaks exceeds the intensity of silver sulphide peaks several times in $2 \theta \leq 20^{\circ}$. Therefore, XRD diffractograms of samples were recorded in the $2 \theta$ range between 22 and $60^{\circ}$.

Figure 5 presents the X-ray diffraction pattern of the as-prepared $\mathrm{Ag}_{2} \mathrm{~S} / \mathrm{PP}$ composites. The phase composition was determined by comparing $\mathrm{Ag}_{2} \mathrm{~S} / \mathrm{PP}$ composites $\mathrm{XRD}$ diffraction patterns with those of known minerals.

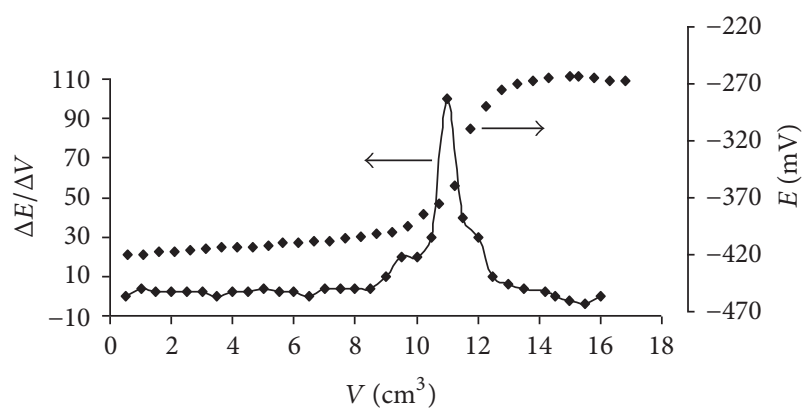

FIGURE 7: Potentiometric curves for the titration of $0.0024 \mathrm{~mol} / \mathrm{dm}^{3}$ thiamine with $0.01 \mathrm{~mol} / \mathrm{dm}^{3}$ silver nitrate solutions in alkaline medium using $\mathrm{Ag}_{2} \mathrm{~S} / \mathrm{PP}$ layer as an indicator electrode. Electrode prepared in $0.08 \mathrm{~mol} / \mathrm{dm}^{3} \mathrm{AgNO}_{3}$ and $0.20 \mathrm{~mol} / \mathrm{dm}^{3} \mathrm{Na}_{2} \mathrm{~S}_{2} \mathrm{O}_{3}$ solutions at $20^{\circ} \mathrm{C}$ for $200 \mathrm{~min}$.

Diffraction pattern gave dominant peaks $2 \theta$ at $26.189^{\circ}$ (the crystallographic planes $(111), 29.063^{\circ}(012), 31.820^{\circ}(120)$, $33.666^{\circ}(121), \quad 34.743^{\circ}(112), \quad 36.806^{\circ}(022), \quad 37.6^{\circ}(200)$, $40.798^{\circ}(031), 43.47^{\circ}(130), 46.28^{\circ}(202)$, and $\left.53.21^{\circ}(004)\right)$ and showed the polycrystalline nature of the prepared $\mathrm{Ag}_{2} \mathrm{~S}$ layer. The diffraction patters were indexed to the monoclinic $\mathrm{Ag}_{2} \mathrm{~S}$ phase and are in good agreement with the reported data for $\alpha-\mathrm{Ag}_{2} \mathrm{~S}$ (acanthite) (JCPDS Card File: 00-014-0072).

3.7. Application of $\mathrm{Ag}_{2} \mathrm{~S} / \mathrm{PP}$ Layers for Potentiometric Measurements. To assess the practical applicability of the prepared silver sulphide layer on polypropylene films, an attempt was made to test $\mathrm{Ag}_{2} \mathrm{~S} / \mathrm{PP}$ composite as an $\mathrm{Ag}^{+}$ion selective electrode.

For analytical applications, the response time of a sensor is an important factor. The average time to reach a potential within $\pm 1 \mathrm{mV}$ of its final equilibrium value was measured after successive immersion of the $\mathrm{Ag}_{2} \mathrm{~S} / \mathrm{PP}$ composite electrode in a series of $\mathrm{AgNO}_{3}$ solutions of different concentration, each having a 10 -fold increase in $\mathrm{Ag}^{+}$ion concentration from $1.0 \times 10^{-8}$ to $1.0 \times 10^{-2} \mathrm{~mol} / \mathrm{dm}^{3}$. The ionic strength of solutions was $0.1 \mathrm{~mol} / \mathrm{dm}^{3}$. The static response time for $\mathrm{Ag}_{2} \mathrm{~S} / \mathrm{PP}$ composite electrode obtained was $20 \mathrm{~s}$ for $1 \times 10^{-2} \mathrm{~mol} / \mathrm{dm}^{3} \mathrm{Ag}^{+}$ion concentration, while at lower concentrations the response time increased up to $60 \mathrm{~s}$.

A linear potential response was obtained in the concentration range from $1 \times 10^{-2}$ to $1 \times 10^{-5} \mathrm{~mol} / \mathrm{dm}^{3}$ (Figure 6). The change in slope per decade change in $\mathrm{Ag}^{+}$ion concentration was found to be slightly lower than that of $25.6 \mathrm{mV}$ decade for a theoretical Nernstian response, which is the expected value for a univalent ion. A potential deviation from linear behaviour was observed in the concentration range below $1 \times 10^{-6} \mathrm{~mol} / \mathrm{dm}^{3}$.

The $\mathrm{Ag}_{2} \mathrm{~S} / \mathrm{PP}$ composite electrode was also tested as an end-point indicator electrode in potentiometric titration involving $\mathrm{Ag}^{+}$ions. The method can be applied for the determination of thiamine hydrochloride.

In highly alkaline medium, thiamine undergoes chemical transformation and loses two protons through two distinct 
dissociation steps. The reaction occurs through intramolecular addition of the amino group of thiamine to the thiazolium ring with loss of first proton, accompanied by opening of the thiazole ring and loss of a second proton [51]. These protons can be replaceable by $\mathrm{Ag}^{+}$ions. In presence of sodium hydroxide, the silver ions do not react with free chloride but react with thiols only [52].

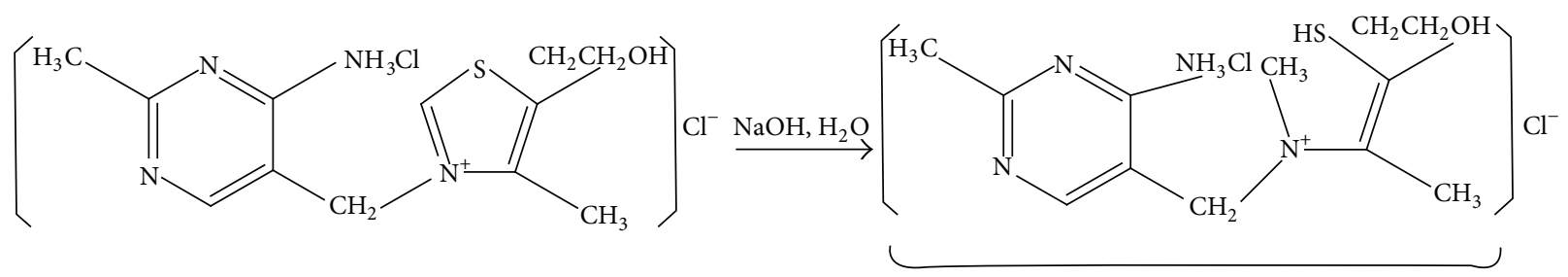

$$
\mathrm{RSH}+\mathrm{Ag}^{+} \rightleftarrows \mathrm{RSAg}+\mathrm{H}^{+}
$$

The solubility product of $\mathrm{AgOH}\left(K_{\mathrm{sp}}=2 \times 10^{-8}\right)$ is higher than that of $\operatorname{AgCl}\left(K_{\mathrm{sp}}=1.78 \times 10^{-10}\right)$; therefore, the precipitation of $\mathrm{AgCl}$ would be suppressed by the addition of $\mathrm{NaOH}$ excess. In alkaline medium, $\mathrm{Ag}_{2} \mathrm{~S} / \mathrm{PP}$ does not respond to $\mathrm{HO}^{-}$ions; hence, this electrode can be used as an indicator electrode for the determination of thiamine content in vitamin $B_{1}$.

The potentiometric titration curves of $0.0024 \mathrm{~mol} / \mathrm{dm}^{3}$ thiamine with $0.01 \mathrm{~mol} / \mathrm{dm}^{3}$ silver nitrate in alkaline medium are shown in Figure 7 . There is a clear potential break (Figure 7) corresponding to the consumption of 0.78 mole of silver nitrate per mole of thiamine.

\section{Conclusions}

$\mathrm{Ag}_{2} \mathrm{~S}$ layers were successfully prepared at $20^{\circ}$ temperature on polypropylene (PP) immersed in a bath containing the aqueous solutions of $0.08 \mathrm{~mol} / \mathrm{dm}^{3}$ silver nitrate and $0.2 \mathrm{~mol} / \mathrm{dm}^{3}$ sodium thiosulphate solution. The surface morphology, texture, and uniformity of the silver sulphide layers formed on PP surface dependent on the number of polymer immersions in the precursor solution. Chemical and X-ray photoelectron spectroscopy analyses confirmed a formation of silver sulphide on polypropylene surface. ATR-FTIR and FTIR spectra analysis showed that the surface of $\mathrm{Ag}_{2} \mathrm{~S}$ layers is slightly oxidized. The XRD studies indicated that the deposited layers were polycrystalline with monoclinic (acanthite) crystal structure. The $\mathrm{Ag}_{2} \mathrm{~S} / \mathrm{PP}$ sensor exhibited low detection limit and therefore, are promising as indicating electrode in argentometric titration of vitamin $B_{1}$ as well as a sensor for determination of silver ions.

\section{References}

[1] V. Krylova and N. Dukštienè, "Characterization of $\mathrm{Cu}_{x} \mathrm{~S}$ layers obtained by adsorption-diffusion method on polycaproamide from $\mathrm{K}_{2} \mathrm{~S}_{5} \mathrm{O}_{6}$ solutions," Polish Journal of Chemistry, vol. 80, no. 9, pp. 1435-1447, 2006.
[2] V. Krylova, "Spectroscopic and diffraction studies of chemical deposition of copper sulfide films on polyamide surface using potassium pentathionate," Materials Science-Poland, vol. 25, no. 4, pp. 933-945, 2007.

[3] F. I. Eczema, P. U. Asogwa, A. B. C. Ekwealor, P. E. Ugwuoke, and R. U. Osuji, "Growth and optical properties of $\mathrm{Ag}_{2} \mathrm{~S}$ thin films deposited by chemical bath deposition technique," Journal of the University of Chemical Technology and Metallurgy, vol. 42, no. 2, pp. 217-222, 2007.

[4] V. Krylova and M. Andruleviçius, "Optical, XPS and XRD studies of semiconducting copper sulfide layers on a polyamide film," International Journal of Photoenergy, vol. 2009, Article ID 304308, 8 pages, 2009.

[5] R. R. Pradhananga and L. K. Shrestha, "Application of Ag-ion selective electrode for the determination of solubility products of different sparingly soluble silver salts," Analytical Sciences, vol. 17, pp. 395-396, 2001.

[6] A. N. Rodríguez, M. T. S. Nair, and P. K. Nair, "Structural, optical and electrical properties of chemically deposited silver sulfide thin films," Semiconductor Science and Technology, vol. 20, no. 6, pp. 576-585, 2005.

[7] B. R. Sankapal, R. S. Mane, and C. D. Lokhande, "New chemical method for the preparation of $\mathrm{Ag}_{2} \mathrm{~S}$ thin films," Materials Chemistry and Physics, vol. 63, no. 3, pp. 226-229, 2000.

[8] S. S. Dhumure and C. D. Lokhande, "Studies on the preparation and characterization of chemically deposited $\mathrm{Ag}_{2} \mathrm{~S}$ films from an acidic bath," Thin Solid Films, vol. 240, no. 1-2, pp. 1-6, 1994.

[9] I. A. Ezenwa, N. A. Okereke, and N. J. Egwunyenga, "Optical properties of chemical bath deposited $\mathrm{Ag}_{2} \mathrm{~S}$ thin films," International Journal of Science and Technology, vol. 2, no. 3, pp. 101-106, 2012.

[10] T. B. Nasrallah, H. Dlala, M. Amlouk, S. Belgacem, and J. C. Bernède, "Some physical investigations on $\mathrm{Ag}_{2} \mathrm{~S}$ thin films prepared by sequential thermal evaporation," Synthetic Metals, vol. 151, no. 3, pp. 225-230, 2005.

[11] J. A. Muñoz, C. Gómez, A. Ballester, M. L. Blázquez, F. González, and M. Figueroa, "Electrochemical behaviour of chalcopyrite in the presence of silver and Sulfolobus bacteria," Journal of Applied Electrochemistry, vol. 28, no. 1, pp. 49-56, 1997. 
[12] M. C. Brelle and J. Z. Zhang, "Femtosecond study of photoinduced electron dynamics in AgI and core/shell structured $\mathrm{Agl} / \mathrm{Ag}_{2} \mathrm{~S}$ and $\mathrm{AgBr} / \mathrm{Ag}_{2} \mathrm{~S}$ colloidal nanoparticles," Journal of Chemical Physics, vol. 108, no. 8, pp. 3119-3126, 1998.

[13] A. P. Yadav and R. R. Pradhananga, "Preparation and characterization of silver sulphide/silver iodide ion selective electrodes for the determination of $\mathrm{I}^{-}, \mathrm{S}^{2-}$ and $\mathrm{Ag}^{+}$ions," Journal of Nepal Chemical Society, vol. 15, no. 9, pp. 19-26, 1996.

[14] Y. Umezawa, P. Bühlmann, K. Umezawa, K. Tohda, and S. Amemiya, "Potentiometric selectivity coefficients of ionselective electrodes part I. Inorganic cations," Pure and Applied Chemistry, vol. 72, no. 10, pp. 1851-2082, 2000.

[15] R. R. Pradhananga and A. Rajbhandari, "Low cost electrochemical sensors for silver, chloride, bromide and iodide ions," Scientific World, vol. 6, no. 6, pp. 33-36, 2008.

[16] X. Lu, L. Li, W. Zhang, and C. Wang, "Preparation and characterization of $\mathrm{Ag}_{2} \mathrm{~S}$ nanoparticles embedded in polymer fibre matrices by electrospinning," Nanotechnology, vol. 16, no. 10, pp. 2233-2237, 2005.

[17] R. V. Kumar, O. Palchik, Y. Koltypin, Y. Diamant, and A. Gedanken, "Sonochemical synthesis and characterization of $\mathrm{Ag}_{2}$ S/PVA and CuS/PVA nanocomposite," Ultrasonics Sonochemistry, vol. 9, no. 2, pp. 65-70, 2002.

[18] K. Akamatsu, S. Takei, M. Mizuhata et al., "Preparation and characterization of polymer thin films containing silver and silver sulfide nanoparticles," Thin Solid Films, vol. 359, no. 1, pp. 55-60, 2000.

[19] J. Y. Wang, W. Chen, A. H. Liu et al., "Controlled fabrication of cross-linked nanoparticles/polymer composite thin films through the combined use of surface-initiated atom transfer radical polymerization and gas/solid reaction," Journal of the American Chemical Society, vol. 124, no. 45, pp. 13358-13359, 2002.

[20] C. Maier and T. Calafut, Polypropylene: The Definitive User's Guide and Databook, William Andrew, 1998.

[21] R. S. Mane and C. D. Lokhande, "Chemical deposition method for metal chalcogenide thin films," Materials Chemistry and Physics, vol. 65, no. 1, pp. 1-31, 2000.

[22] D. N. Okoli, G. C. Okeke, and A. J. Ekpunobi, "Optical properties of chemical bath deposited $\mathrm{Ag}_{2} \mathrm{~S}$ thin films," Pacific Journal of Science and Technology, vol. 11, no. 1, pp. 411-415, 2010.

[23] D. K. Božanić, V. Djoković, J. Blanuša, P. S. Nair, M. K. Georges, and T. Radhakrishnan, "Preparation and properties of nanosized $\mathrm{Ag}$ and $\mathrm{Ag}_{2} \mathrm{~S}$ particles in biopolymer matrix," European Physical Journal E, vol. 22, no. 1, pp. 51-59, 2007.

[24] U. M. Jadhav, S. R. Gosavi, S. N. Patel, and R. S. Patil, "Studies on characterization of nanocrystalline silver sulphide thin films deposited by chemical bath deposition (CBD) and successive ionic layer adsorption and reaction (SILAR) method," Archives of Physics Research, vol. 2, no. 2, pp. 27-35, 2011.

[25] Y. Gotoh, T. Kanno, Y. Fujimori et al., "Introduction of Ag and $\mathrm{Ag}_{2} \mathrm{~S}$ nanoparticles into nylon 6 film and fiber," Polymer Journal, vol. 35, no. 12, pp. 960-964, 2003.

[26] W. Zhang, L. Zhang, Z. Hui, X. Zhang, and Y. Qian, "Synthesis of nanocrystalline $\mathrm{Ag}_{2} \mathrm{~S}$ in aqueous solution," Solid State Ionics, vol. 130, no. 1, pp. 111-114, 2000.

[27] S. S. Dhumure and C. D. Lokhande, "Chemical deposition of $\mathrm{Ag}_{2} \mathrm{~S}$ films from acidic bath," Materials Chemistry and Physics, vol. 28, no. 1, pp. 141-144, 1991.
[28] X. F. Qian, J. Yin, J. C. Huang, Y. F. Yang, X. X. Guo, and Z. K. Zhu, "Preparation and characterization of PVA/Ag $\mathrm{S}$ nanocomposite," Materials Chemistry and Physics, vol. 68, no. 1-3, pp. 95-97, 2001.

[29] A. Vogel, Text Book of Guantitative Chemical Analysis I, Longman Scietific \& Technical, London, UK, 1989.

[30] D. Briggs and M. P. Seach, Analiz poverkhnosti metodami ozhe i rentgenovskoj fotoelektronnoj spectroskopii, Mir, Moscow, Russia, 1987.

[31] National Institute of Standards and Technology, "NIST online databases, X-ray photoelectron spectroscopy database," 2012, http://srdata.nist.gov/xps/.

[32] R. A. Lidin, L. L. Andrejeva, and V. A. Molochko, Reference Book on Inorganic Chemistry, Khimiya, Moscow, Russia, 1987.

[33] C. D. Wagner, W. M. Riggs, L. E. Davis, and J. F. Moulder, Handbook of X-Ray Photoelectron Spectroscopy, Perkin-Elmer, Waltham, Mass, USA, 1978.

[34] J. Vinkevičius, I. Možginskiene, and V. Jasulaitiene, "Investigations of the interaction between $\mathrm{Cu}_{2-x} \mathrm{~S}$ coating and $\mathrm{Ag}(\mathrm{I})$ ions using cyclic voltammetry and $\mathrm{X}$-ray photoelectron spectroscopy," Journal of Electroanalytical Chemistry, vol. 442, no. 1-2, pp. 73-82, 1998.

[35] R. Chen, N. T. Nuhfer, L. Moussa, H. R. Morris, and P. M. Whitmore, "Silver sulfide nanoparticle assembly obtained by reacting an assembled silver nanoparticle template with hydrogen sulfide gas," Nanotechnology, vol. 19, no. 45, Article ID 455604, 11 pages, 2008.

[36] V. Djoković, R. Krsmanović, D. K. Božanić et al., "Adsorption of sulfur onto a surface of silver nanoparticles stabilized with sago starch biopolymer," Colloids and Surfaces B, vol. 73, no. 1, pp. 30-35, 2009.

[37] C. J. Powell, "Elemental binding energies for X-ray photoelectron spectroscopy," Applied Surface Science, vol. 89, no. 2, pp. 141-149, 1995.

[38] G. Hota, S. B. Idage, and K. C. Khilar, "Characterization of nanosized CdS- $\mathrm{Ag}_{2} \mathrm{~S}$ core-shell nanoparticles using XPS technique," Colloids and Surfaces A, vol. 293, no. 1-3, pp. 5-12, 2007.

[39] D. J. Asunskis and L. Hanley, "Valence band and core level $\mathrm{X}$-ray photoelectron spectroscopy of lead sulfide nanoparticlepolymer composites," Surface Science, vol. 601, no. 19, pp. 4648-4656, 2007.

[40] T. X. Liu, X. Z. Li, and F. B. Li, "AgNO ${ }_{3}$-induced photocatalytic degradation of odorous methyl mercaptan in gaseous phase: mechanism of chemisorption and photocatalytic reaction," Environmental Science and Technology, vol. 42, no. 12, pp. 4540-4545, 2008.

[41] J. S. Hammond, S. W. Gaarenstroom, and N. Winograd, "X-ray photoelectron spectroscopic studies of cadmium- and silveroxygen surfaces," Analytical Chemistry, vol. 47, no. 13, pp. 2193-2199, 1975.

[42] B. J. Murray, Q. Li, J. T. Newberg, E. J. Menke, J. C. Hemminger, and R. M. Penner, "Shape- and size-selective electrochemical synthesis of dispersed silver(l) oxide colloids," Nano Letters, vol. 5, no. 11, pp. 2319-2324, 2005.

[43] M. Bielmann, P. Schwaller, P. Ruffieux, O. Gröning, L. Schlapbach, and P. Gröning, "AgO investigated by photoelectron spectroscopy: evidence for mixed valence," Physical Review B, vol. 65, no. 23, Article ID 235431, 5 pages, 2002.

[44] B. H. Stuart, Infrared Spectroscopy: Fundamentals and Aplications, John Wiley \& Sons, New York, NY, USA, 2002. 
[45] E. Pretsch, P. Bühlmann, and M. Badertscher, Structure Determination of Organic Compounds: Tables of Spectral Data, Springer, Berlin, Germany, 4th edition, 2009.

[46] G. Nickless, Inorganic Sulphur Chemistry, Elsevier, Amsterdam, The Netherlands, 1968.

[47] L. J. Belamy, Infrared Spectra of Inorganic and Coordination Compounds, John Wiley \& Sons, New York, NY, USA, 1963.

[48] R. A. Nyquist and R. O. Kagel, Infrared Spectra of Inorganic Compounds, Academic Press, New York, NY, USA, 1971.

[49] K. Nakamoto, Infrared and Raman Spectra of Inorganic and Coordination Compounds, Part A, John Wiley \& Sons, New York, NY, USA, 5th edition, 1997.

[50] J. C. Lindon, G. E. Tranter, and J. L. Holmes, Encyclopedia of Spectroscopy and Spectrometry, Academic Press, New York, NY, USA, 2000.

[51] A. Rajbhandari, A. P. Yadav, K. Manandhar, and R. R. Pradhananga, "Characterization and applications of silver sulphide based membrane electrodes," Scientific World, vol. 7, no. 7, pp. 19-23, 2009.

[52] S. S. M. Hassan and E. Elnemma, "Selective determination of thiamine (vitamin B1) in pharmaceutical preparations by direct potentiometric argentometric titration with use of the silversilver sulphide ion-selective electrode," Talanta, vol. 36, no. 10, pp. 1011-1015, 1989. 

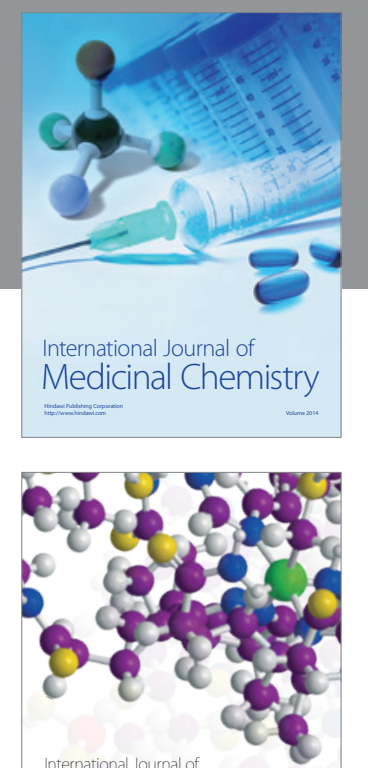

\section{Carbohydrate} Chemistry

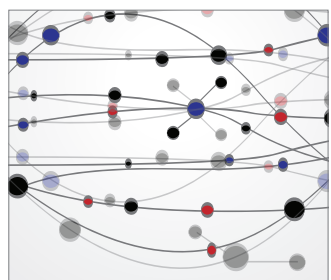

The Scientific World Journal
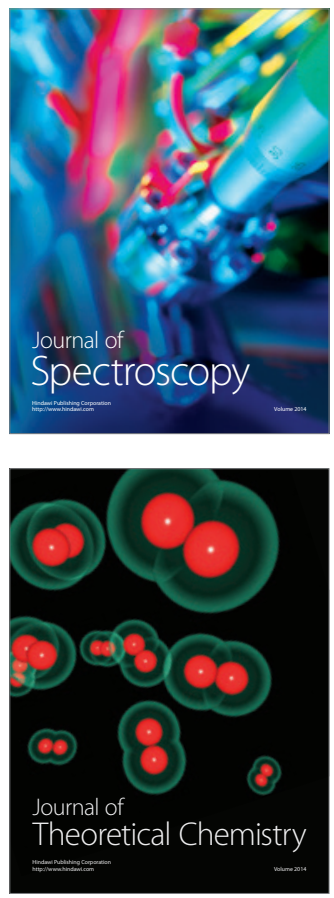
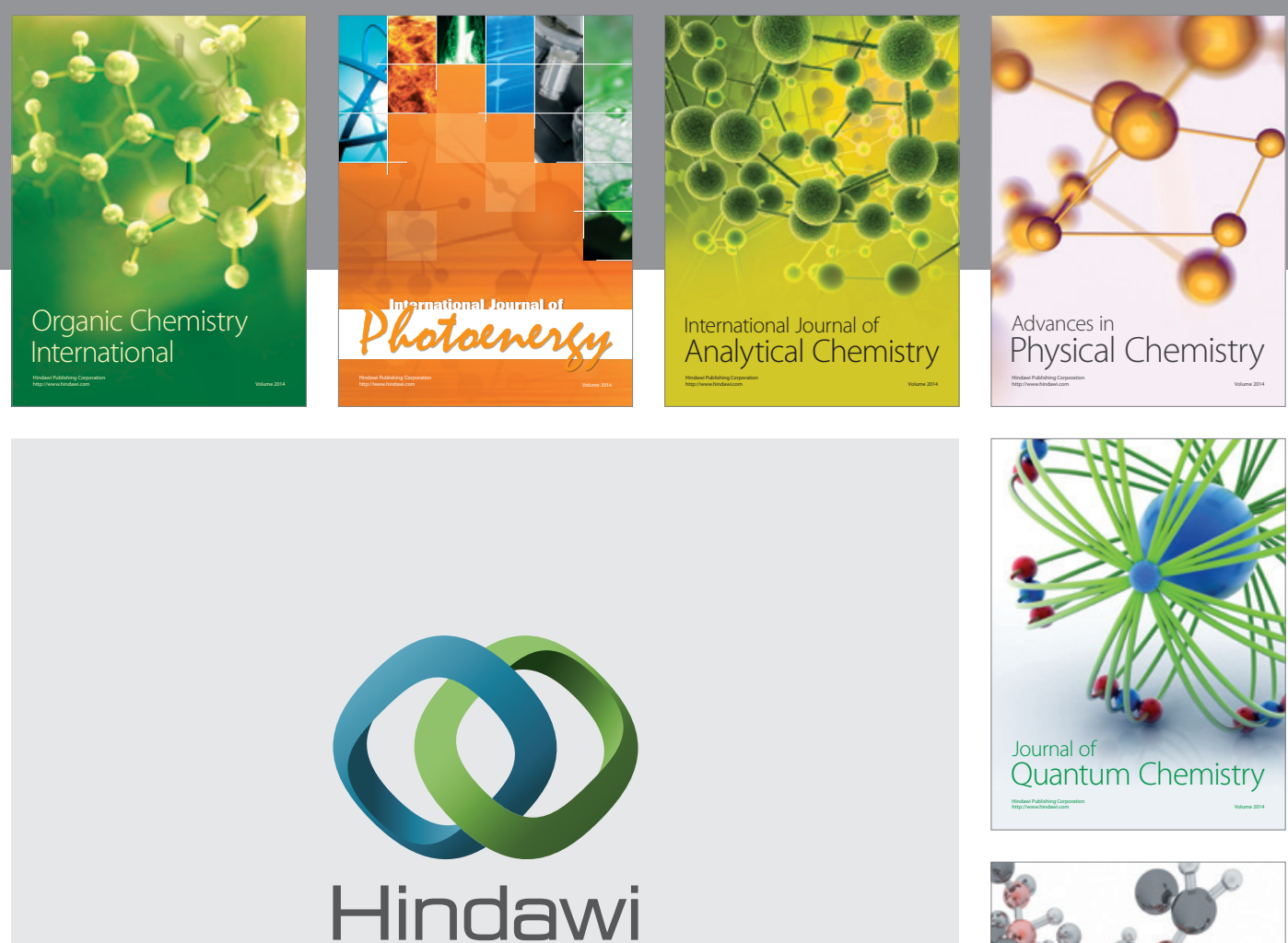

Submit your manuscripts at

http://www.hindawi.com

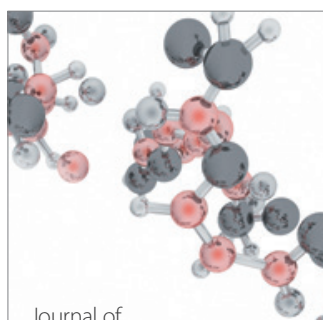

Analytical Methods

in Chemistry

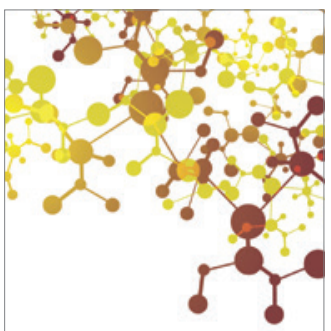

Journal of

Applied Chemistry

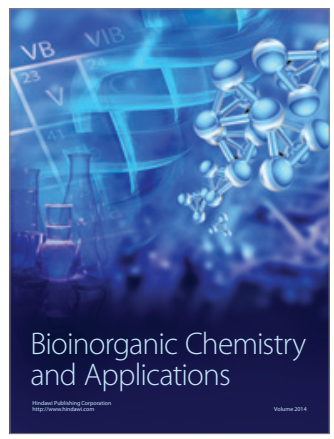

Inorganic Chemistry
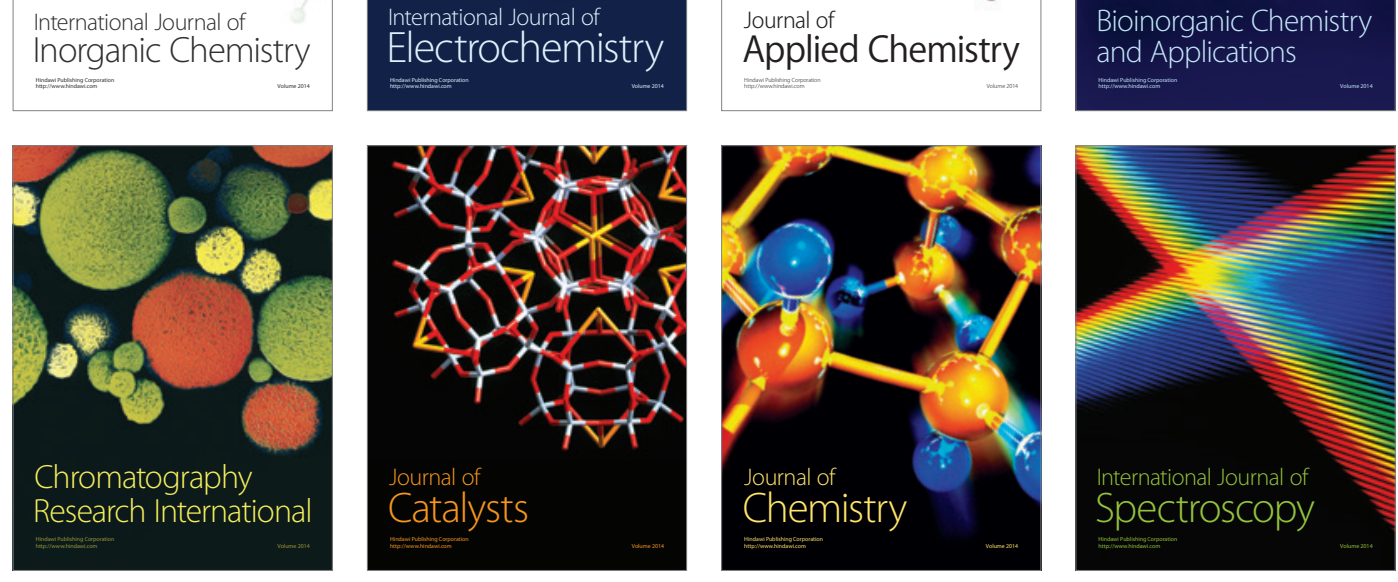